\title{
FOORUM
}

\section{Milline on Eesti ajalooteaduse tulevik?}

Kui teemanumbri seitse artiklit võtsid tagasivaatavalt vaagida Eesti ajalooteaduse arengusuundi viimasel kahel kümnendil, siis siinse foorumi seitse lühiesseed heidavad vastukaaluks pilgu ettepoole, arutledes Eesti ajalooteaduse võimalike suundumuste üle järgmisel kahel aastakümnel. Ettepanek foorumisse panustada sai tehtud teadlikult vaid nendele eri põlvkondade Eesti ajaloolastele - doktorandist emeriitprofessoriteni -, kes on mõnda aega tegutsenud või tegutsevad praegu välismaa ülikoolides. Selle valiku taga on lihtne soov pakkuda avaramat vaadet, $n$-ö kõrvalt pilku, mida teises ühiskonnas töötamine eelduspäraselt pakub. Ühtlasi võib valikut käsitada tunnismärgina sellest, et uuel sajandil on üha enam Eesti ajaloolasi leidnud rakendust nimekates ülikoolides üle ilma. Tänan siinkohal toimetuse nimel kõiki, kes leidsid võimaluse ettepanek vastu võtta. Mõtteliselt võib siinse foorumi siduda kahekümne aasta taguse katsetusega ajakirjas Vikerkaar, kus palusin kümmekonnal Eesti ajaloolasel arutleda lühiessee vormis küsimuse üle „Kuidas kirjutada Eesti ajalugu“. ${ }^{1}$ Jääb vaid loota, et hiljemalt 2040. aastal saab see mõtteline traditsioon uue järje.

\section{LIISI ESSE (Stanfordi Ülikool):}

Eesti ajalooteadus on teinud viimastel aastakümnetel läbi rea tormilisi arenguid. Hulk varasemalt varju jäänud või sootuks katmata teemasid ja allikaid on praeguseks tänapäevase ning eripalgelise metoodika najal suurt tähelepanu pälvinud. Muu maailma, eriti lääne kolleegidega on sõlmitud tihedad sidemed ning Eesti teadlaste töid loetakse ja hinnatakse kodus ja kaugemalgi. Senised saavutused ja peale kasvanud põlvkonnad noori ajaloolasi annavad lootust, et positiivne trend jätkub. Milline võiks olla või peaks olema Eesti ajalooteadus lähitulevikus? Milliste teemadega võiksid praegu ülikooli astuvad noored mõne, kümne või paarikümne aasta möödudes tegeleda?

Kuivõrd põhjalikumat käsitlemist ootavaid küsimusi ja allikaid leiab iga ajalooteema juures, võib eeldada, et meie ajalooteaduse edasisest arengust moodustab lõviosa senises historiograafias juba ühel või teisel viisil puudutatud teemade rafineeritum ja komplekssem käsitlus. Viimast täiendab erialadevahelise koostöö arendamine ning uute meetodite, näiteks tänini pigem tagasihoidlikku kasutust leidnud digihumanitaaria võimaluste rakendamine. Seejuures võiks Eesti ajalooteadus

1 Jaanson, K., Jansen, E., Piirimäe, E. ja P., Pirsko, P., Rebas, H., Rosenberg, T., Ruutsoo, R., Undusk, J., T[amm], M. Foorum: Kuidas kirjutada Eesti ajalugu? - Vikerkaar, 2000, 8-9, 178-190. 
senisest veelgi laialdasemalt põimuda regionaalse ja globaalse ajalookirjutusega. Meie teemadest ja järeldustest selle „miski“ leidmine, mis kõnetaks rahvusvahelist uurijaskonda, aitab nii mõnigi kord ka meie enda jaoks eraldada olulist vähem olulisest ning asetada kohalikus kontekstis harjumuspäraselt mõistetavad küsimused uude valgusesse.

Arvestatav osa Eesti ajaloolaste tähelepanust kandub järgnevail aastail meie lähiajaloole 1980. aastate teisel poolel ning iseseisvuse taastanud Eesti arengule 1990. aastatel. Tegemist on olulise lüngaga, mis ehk kuni väga hiljutise ajani sellisena pole paistnudki: üleminek ,(lähi)minevikust“ „ajaloo“ staatusesse on kompleksne ning kaasaegsetele sageli märkamatu. Praeguse põlvkonna ajalootudengite magistrija doktorikraadide kaitsmise ajal (vähem skeptilise hinnangu kohaselt aga ehk juba nüüdki!) võib Eesti taasiseseisvumise teed uurida selle liigset värskust ja politiseeritust pelgamata. Seetõttu tasub heita ettevaatav pilk küsimustele ja võimalustele, mis antud teemaderingi käsitlemisel esile võiks kerkida.

Sarnaselt äsja suuremat uurijate tähelepanu pälvinud Eesti riikluse loomise ja Vabadussõjaga on iseseisvuse taastamine ja selle eellugu 1980. aastatel vastuvaidlematu tähtsusega murranguperiood riigi, aga ka siinse rahva jaoks. Samavõrd olulisena võib näha Eesti arengut 1990. aastatel. Kuidas riik taasloodi? Millised olid poliitilis-majandusliku juhtkonna õnnestumised ja ebaõnnestumised, kuidas mõjutasid need ühiskonda laiemalt ja inimesi eraldi? Kuidas ehitati üles Eesti riigi maine ja rahvusvahelised sidemed? Mil viisil arenesid suhted Venemaaga, milline oli siinse vene vähemuse staatus? Kuidas toimus majanduslik, ühiskondlik, kultuuriline ja olmeline areng? Sotsiaal- ja riigiteadlaste ning kultuuriloolaste kõrval on üksikud ajaloolased asunud neid küsimusi uurima, ${ }^{2}$ ent suur osa loetletud teemadest on leidnud kajastamist pigem aime- ja ülevaateteostes (mis tuginevad sageli küll soliidsele allikabaasile) või kaasaegsete mälestustes ning alles ootab teadlaste süvauurimusi. ${ }^{3}$ Arhiividesse ja muuseumikogudesse on nüüdseks 1980.-1990. aastaid kajastavaid allikaid kogunenud piisavalt, uurimisainest pakuvad rohkearvulised memuaarid ja intervjuud ning sündmuste keerises viibinud inimeste erakogud. ${ }^{4}$

Üha populaarsemaks saanud meetodina 20. sajandi sündmusi pika aegrea kontekstis käsitledes ning mitmesuguseid järjepidevusi ja katkestusi analüüsides tasuks küsida, kas ja kuidas on võimalik kõrvutada Eesti Vabariigi n-ö kaht algust, 1920. aastate ja 1990. aastate arengut. ${ }^{5}$ Kuidas mõjutasid ühiskonda tabanud suured rapu-

2 Vt Vello Pettai, Eva-Clarita Pettai, Raivo Vetiku, Juhan Kivirähki, Andres Kasekampi, Marju Lauristini, Peeter Vihalemma, Mati Heidmetsa ja Ene Kõresaare uurimusi ja kogumikke taasiseseisvunud Eesti (mälu)poliitilisest, majanduslikust ja ühiskondlikust arengust. Ajalookäsitlusi ja -kogumikke on ilmunud näiteks Marek Tamme ja Pille Petersoo, Reigo Loki, Mati Grafi jt sulest.

3 Vt nt Tarmo Vahteri, Enno Tammeri, Tiit Made, Edgar Savisaare, välisministeeriumi ja välisesinduste, mitmete seltside jpt kogumikke, mälestusi ning allika- ja juubelipublikatsioone.

4 Vt ka: Tannberg, T. Lähiajalugu ja arhiivid: milliseid uurimisvõimalusi pakuvad Eesti iseseisvuse taastamisprotsessi uurimisel arhiiviallikad. - Meie vabaduse mitu nägu: Konverents Tartus 29. septembril 2012 lähiajaloost, selle uurimisest ja kajastamisest. Koost ja toim L. Hainsalu, R. Järlik. 20. Augusti Klubi, Tartu, 2013, 149-158.

5 Vt ka: Ant, J. Kaks algust: võrreldavus ja võrreldamatus. - Kaks algust: Eesti Vabariik - 1920. ja 1990. aastad. Koost ja toim J. Ant. Umara, Tallinn, 1998, 138-143. 
tused inimeste eluolu ja toimetulekut, aga ka mälupraktikaid? Kuivõrd toetus poliitiline ja ühiskondlik ladvik 1990. aastatel maailmasõdade vahelise Eesti ideestikule ning, eriti ühiskonda mobiliseeriva vahendina, varasema perioodi rahvuslikule identiteedile? Kuidas toimus (taas)iseseisvumisse panustanud või selle vastu aktiivselt võidelnud isikute ja gruppide tegevuse hindamine kollektiivse mälu ja riiklikul tasandil ning mil viisil lahendati vähemuste küsimus? Kuivõrd oskuslikult kasutati 1990. aastatel ära maailmasõdadevahelisi kogemusi ja õppetunde?

Eesti iseseisvuse taastamine ja taasiseseisvunud Eesti areng omab lisaks lokaalsele, siinsete elanike jaoks vastuvaidlematule olulisusele ka regionaalset ja rahvusvahelist mõõdet. Taasiseseisvumine ning sellele eelnenud ja järgnenud protsessid moodustasid osa globaalsest murranguperioodist, mis on tihedalt seotud Nõukogude Liidu ja selle annekteeritud territooriumide ja satelliitriikide, Venemaa ning Euroopa riikide ja USA ajalooga. Uurimist väärivad Baltimaade ning Balti- ja Põhjamaade regionaalne koostöö, siinse piirkonna areng, koostöö Venemaa suunal jpm.

Vaadeldes Eestit puudutavaid uuemaid käsitlusi rahvusvahelises ajalookirjutuses, paistab kasvav huvi 1980.-1990. ning isegi 2000. aastate vastu teravalt silma. Eesti ja laiemalt Balti riikide näide huvitab uurijaid, kes analüüsivad, kuidas on toimunud riikide, ühiskondade ja rahvaste liikumine diktatuurist demokraatiasse ning mida see protsess sündmuste keskmes olevatele inimestele tähendab. Üldiselt peetakse Balti riike demokratiseerumise positiivseks näiteks; põhjalikumalt on käsitletud Eesti julgeolekut (sh küberturvalisust) ja vene vähemuse temaatikat, haridus- ja keelepoliitikat, mälu- ja identiteediküsimusi. ${ }^{6}$ Lähiaastatel võiks oodata, et ilmub üha rohkem võrdlevaid käsitlusi, mis kõrvutavad Eesti ja Baltikumi arengut 1990.2000. aastate Venemaa ja teiste endiste idabloki riikide arenguga.

Eesti riikluse taastamine ja ühiskonna areng 1990. aastatel on ääretult mitmetahuline ning paljuski alles avastamist ootav teemadering. Sellest johtuvad küsimused pakuvad võimalusi nii võrdlusmomentide kaudu ülejäänud 20. sajandi ajaloo käsitluse rikastamiseks kui ka meie lokaalsete küsimuste rahvusvahelisse konteksti asetamiseks. Loodan, et teema pälvib juba lähiaastatel uurijate aktiivset tähelepanu.

\section{ANDRES KASEKAMP (Toronto Ülikool):}

Järgnevalt mõned tähelepanekud ja uitmõtted Eesti ajalooteadusest ning mõned soovitused, vaadates tulevikku. Pole võimatu, et selle käigus murran sisse ka mõnest lahtisest uksest. Keskendun vaid lähiajaloole, mida tunnen kõige paremini.

Eesti lähiajalugu on ikka valdavalt eestlaste ajalugu. Eesti ajalugu peaks aga olema kogu Eestimaa lugu, milles kõik siin elanud rahvuskillud on väärikalt esindatud. Oleks vaja rohkem pingutada, et lõimida põhinarratiivi baltisakslasi, venelasi, rootslasi, juute jt, mitte paigutada neid vaid omaette kastidesse. Õnnestunud näide

\footnotetext{
6 Vt nt Aliide Naylori, Samuli Haataja, Susan W. Brenneri, Mary Hamptoni ja M. Donald Hancocki, Brian M. Mazaneci, Licia Cianetti, Jennie Schulze, Ksenia Maksimovtsova, Josep Soleri, Gundar J. Kingi ja David E. McNabbi, Nicole Lindstromi, Meike Wulfi, Inge Melchiori, Francisco Martínezi jt uurimusi ja kogumikke.
} 
sellisest käsitlusest on Feliks Gornischeffi hiljuti Tartu Ülikoolis kaitstud doktoritöö baltisakslastest Vene impeeriumi diplomaatilises teenistuses. ${ }^{7}$

Oluline on juurutada võrdlevat lähenemist. Peaks olema üsna loomulik, elementaarne, võrrelda Eesti arengut vähemalt lähimate naabritega, Läti, Leedu ja Soomega. Ambitsioonikamalt juba teiste Euroopa riikide ja väikeriikidega mujal maailmas. Võrdlus teistega pakub alati värske vaatevinkli ja aitab paremini mõista enda arengut. Oleme püüdnud edendada seda eesmärki AABS-is ja selle ajakirjas Journal of Baltic Studies, ent enamik laekuvatest käsikirjadest on siiski pühendatud kitsalt vaid ühe Balti riigi või rahva juhtumile. Võrdlevast käsitlusest samm edasi on rahvusülene vaatlusviis, millega tegi otsa lahti Karsten Brüggemanni juhitud uurimisprojekt „Eesti ajaloo rahvusülene raamistik: transkultuurilised põimingud, ülemaailmsed organisatsioonid ja piiriülene ränne“ (2015-2020).

Nagu me kõik teame, on Eesti ajalooteaduse üks üldine häda see, et uurijaid on vähe. Mis tähendab, et tavaliselt juhtub nii, et ühele uurimisteemale jagub üks ajaloolane. Ja kui see üks on oma uurimuse avaldanud, siis võib öelda, et see teema on kaetud ehk ,tehtud“ - rohkem kedagi selle teema peale ei suunata (vähemalt kuni järgmise põlvkonna või riigikorrani). Suuremates ühiskondades on kümneid ajaloolasi, kes uurivad sama teemat, kasutades eri meetodeid või vaatenurki. Suur kaklus kümmekonna aasta eest vanade sõprade Magnus Ilmjärve ja Jaak Valge vahel tulenes osalisest sellest, et viimane vaatas läbi samad arhiivitoimikud kui esimene, aga jõudis hoopis teistsuguste järeldusteni. Eesti oludes oli see ennekuulmatu ja täiesti ootamatu (ning seda peeti isegi ebaviisakaks), et teine ajaloolane uurib sama küsimust, loeb arhiivis samu dokumente ja kirjutab midagi risti vastupidist.

Teine üldine häda Eesti humanitaar- ja sotsiaalteadustes laiemalt on see, et tihtipeale tehakse juhuslikku allhanget, selmet keskenduda enda püstitatud uurimuslikele eesmärkidele. Tunnistan kohe, et olen ka ise selle vastu eksinud. Näiteks tuleb mõni teadlane Inglismaal välja ideega avaldada kogumik teatud teemal ja otsib autorit, kes võiks kirjutada selle tarbeks Eesti või Balti riikide peatüki. Sellel inglise kolleegil on taskus Routledge'i või mõne teise ETIS-es 3.1 nimekirja kuuluva kirjastuse leping. Ahvatlus on suur - nii on avaldamine tagatud ja võimalus saada rahvusvaheline publikatsioon hõlpsasti kirja. Tegelik eesmärk peaks aga olema hoopis enda teemaga mõnda eelretsenseeritud rahvusvahelisse ajakirja jõudmine - ja mitte area studies -ajakirja, mis keskendub üksnes meie geograafilisele piirkonnale, vaid sellisesse teadusajakirja, kus põneva teema uudne käsitlus võiks pälvida ka meie maailmanurgast kaugemal tegutsevate ajaloolaste huvi

Ajaloolased on enamasti ,üksikud hundid“, kes teevad uurimistööd ja kirjutavad üksi. Muidugi avaldatakse ka mitme autoriga uhkeid koguteoseid, aga igaüks neist vastutab selles vaid konkreetse töölõigu eest. Kaasautorsusel, mis on paljudes teistes teadusharudes normiks, on aga oma eelised. Koostöö, s.t kaasautorsus, on hea viis jõuda rahvusvahelisse ajakirja ja enamasti aitab see tugevdada artikli sisu, ühtlasi on see hea võimalus teiselt kolleegilt õppida ja ennast täiendada.

7 Gornischeff, F. Venemaa suhted Preisimaaga Napoleoni sõdade ajal baltisaksa päritolu diplomaatide tegevuse näitel (1806-1812). Tartu Ülikooli Kirjastus, Tartu, 2020. 
Üks oluline oskus, mis vajaks Eesti ajalooteaduses arendamist, on võime eristada, mis on oluline ja mis vähem oluline. Tihtipeale on ajaloolasel kiusatus eksponeerida kõiki oma arhiivileide ja raske on jätta vähem tähtis kõrvale. Tulemuseks on telliskivisarnane teos, mida on uhke riiulil vaadata, ent mida vähesed loevad algusest lõppuni. Ajaloolane peaks mõtlema oma lugejate peale. Ma ei väida, et monograafiat peaks kirjutama põneviku stiilis, kuid ajaloolane peab olema teadlik nendest, keda ta oma teosega kõnetada soovib. Huvi ajalooeriala vastu on languses mitmel pool maailmas (Põhja-Ameerika ülikoolides on aina vähem sisseastujaid), ent raamatupoed on pilgeni täis ajalooteoseid. Suuremat osa neist raamatutest pole aga kirjutanud ülikoolides töötavad teadlased. Raamatupoodide riiulitel on eriti palju üllitisi sõdadest, ent näiteks Toronto ülikoolis - mille ajaloo-osakond on üks maailma suurimaid - ei leidu ühtegi sõjaajaloolast. Peaksime meeles pidama, et kirjutamine on kunst, mitte teadus, ja liikuma eemale vanast saksa mõistest Geschichtswissenschaft ja lähemale angloameerika Arts and Humanities mõiste juurde, mis näitab paremini, kuhu ajalooteadus kuulub.

Interdistsiplinaarsus on eesmärk, mida on kaua püstitatud, ent mis on visa teostuma. Kuna ma töötasin pikalt Tartu Ülikooli riigiteaduste instituudis, siis sain oma nahal tunda, kuivõrd eraldatud-lahterdatud on kaks ehk teineteisele kõige lähemal seisvat eriala - lähiajalugu ja politoloogia. Kuidagi peaksime ületama politoloogias levinud suhtumise, et ajaloolased tegelevad vaid pisiasjadega ja riigiteadlased suure pildiga. Ajaloolased samal ajal näevad, et politoloogid teevad sageli suuri üldistusi, mis ignoreerivad ajaloolaste töid ja põhinevad aegunud ajalookäsitlusel. Kindlasti tuleks kasuks teineteistelt õppida, ajaloolastel näiteks riigiteadlaste teoreetilisi raamistikke. Üks hea näide on Ago Raudsepa doktoriväitekiri Tartu Ülikooli arheoloogia ja ajaloo instituudis, mis uurib ja võrdleb Soome ja Eesti geopoliitilist olukorda Teise maailmasõja algul, aga mis teeb ka üldisemaid teoreetilisi järeldusi demokraatia ja julgeoleku seostest. ${ }^{8}$

Kui vaadata 20. sajandi uurimisteemasid, mis vajavad rohkem tähelepanu ja kus on lai tööpõld, siis nimetaksin esimesena sõjaeelset Eesti Vabariiki. Välis- ja julgeolekupoliitikat on uuritud peensusteni, aga peaaegu kõik muu tollasest ajastust on jäänud varju. Muidugi on mitmeid uurimusi üksikute asutuste ja riigimeeste kohta, aga 1920.-1930. aastate ühiskondlikest arengutest võiksime palju rohkem teada.

Nõukogude ajast on Stalini-aegsed repressioonid ja vastupanu põhjalikult läbi kammitud, ent Stalini-järgset hilisnõukogude aega on seni vaid pinnapealselt uuritud. Aeg on nii kaugele edasi läinud, et võib ka juba hakata põhjalikumalt uurima 1990. aastate üleminekuaega ja siirdeühiskonda.

Ja muidugi ei tohiks unustada rahvuskaaslasi laias maailmas, nii pagulasi PõhjaAmeerikas kui ka väljarändajaid ja nende järeltulijaid Siberi külades. Oluline on aga paigutada see analüüs laiemasse migratsiooniajaloo konteksti.

Viimastel aastatel on tehtud suuri edusamme selles, et naised oleksid Eesti ajalookäsitlustes rohkem nähtavad. Uurima on hakatud ka soolisi vähemusi, mille heaks näiteks oli Uku Lemberi projekt „Queer-eluilm hilisemas Nõukogude Eestis“

8 Raudsepp, A. Pääsemine ja häving: Demokraatia mõju Soome ja Eesti julgeolekule aastatel 19181948. Tartu Ülikooli Kirjastus, Tartu (ilmumas). 
(2017-2019). Kuid tähelepanu tasub pöörata teistelegi varjujäänud vähemustele, nagu näiteks puuetega inimesed.

Viimastel aastatel on pildile tõusnud keskkonna- ja kliimaajalugu. Selge see, et huvi nende valdkondade vastu kasvab lähiaastatel veelgi. Lõpetuseks, koroonaviiruse järgsel ajal on kindlasti oodata rohkem uurimusi epideemiatest ja haigustest.

\section{JÜRI KIVIMÄE (Toronto Ülikool):}

Ajaloolase ametile on tunnuslik mitte unustada, vaid meelde tuletada, mis juba ununud. Seevastu tulevikku ehk siis seda, mis tuleb ja milliseks kujuneb Eestis ajalookirjutus kahekümne aasta pärast, pole põhimõtteliselt võimalik ette ennustada. Kunagine loova mõtlemise teoreetik Edward de Bono tegi 1995. aastal futuristliku dokumentaalfilmi, mille põhiidee seisneb kujutluses, et 1988. aastal sügavkülmutatud inimesed tuuakse ellu tagasi alles aastal 2040, kui kõik inimkonda ähvardavad haigused on kõrvaldatud. Äsjane koroonaviiruse pandeemia laine, mida ei osatud ennustada, veenis pigem vastupidises, et see tuleviku-unistus ei täitu isegi 20 aasta pärast. Aga tuletame pigem meelde Jacques Le Goffi diktumi: „Ajaloolased oskavad sama vähe tulevikku - sh omaenda distsipliini tulevikku - ennustada nagu teiste teadusalade esindajad (piisab, kui mõtleme näiteks majandusteadlaste arvukatele möödapanekutele).“9

Võib väita, et ajalookirjutus teeb Eestis järgmise kahe aastakümne jooksul läbi eksponentsiaalse kasvu, kuid see on ainult oletus. Niisamuti on kindlalt põhjust arvata, et aastail 2000-2020 toimus samasugune kasv, võrreldes kahe eelneva aastakümnega. Eesti raamatukauplustes leidub lai valik ajalookirjandust, mis üllitatud just viimase 20 aasta sees. Lähemalt vaadeldes satume kimbatusse, sest nii sisult kui mahult on valdavalt tegemist inglise keelest tõlgitud kirjandusega. Kimbatus süveneb, sest ajalookirjutus kui žanr on väga eripärane, ulatudes akadeemilistest üldkäsitlustest, teaduslikest monograafiatest ja artiklikogumikest ning erialastest ajakirjadest kuni elulugudeni, populaarsete ülevaadeteni või koguni alternatiivajalugudeni. Laiema lugejaskonna huvi eestikeelse akadeemilise ajalookirjutuse vastu on vähenenud, sest teaduslik käsitlus ei vasta paljude lugejate ootusele, et ajalool peab olema meelelahutuslik funktsioon, mida täidavad arvutimängud, ajalooteemalised filmid, ajaloosugemetega ulmekirjandus. Sellisel tendentsil on lähitulevikus veel palju arenguruumi.

Kui piirata edasist mõttekäiku diskrimineeriva väitega, et ajalugu uurivad ja kirjutavad peamiselt kutselised ajaloolased, siis jõuame järelduseni, et Eesti praeguste uurivate-kirjutavate ajaloolaste enamus on kindlasti aktiivne ja produktiivne veel kahekümne aasta möödudes. Et jätkuvalt uute töökohtade loomine ajaloo-uurimise vallas on projektiteaduse finantseerimise ja ülikoolide eelarveliste vahendite piiratuse korral vähene ka tulevikus, siis praeguses ajaloolaste kontingendis suuri muutusi ei toimu ja põlvkonnavahetus lükkub tulevikku. Kuna ajaloolaste akadeemilised

9 Tamm, M. Ajalugu, antropoloogia ja imaginaarsus: Intervjuu Jacques Le Goffiga. - Le Goff, J. Raha või elu: Majandus ja religioon keskajal. (Ajalugu. Sotsiaalteadused.) Varrak, Tallinn, 2001, 124. 
profiilid on välja kujunenud, siis ei toimu ajalooteaduses nüüdsega võrreldes ka põhimõttelist paradigmavahetust.

Taasiseseisvumine andis ajalookirjutusele värske energia ja tugeva motivatsiooni. Ajaloo ümber- ja uuestikirjutamine lähtus õigluse restitutsioonist. ${ }^{10}$ Kui veel sajandivahetusel püsis üleskutse - kirjutada oma rahva ajalugu, siis vaatamata suurtele saavutustele on see eesmärk nüüdseks hägustunud. Ehkki ka praegu ja tulevikus oleks otstarbekas arutleda, mis on Eesti ajaloo idee ja kuidas see sobitub laiemasse, üle-euroopalisse ja globaalsesse ajalookultuuri. Mööngem, et ajalookirjutuse eneseanalüüs ehk historiograafia üldkäsitlus on endiselt desideraat, kuigi mitte lihtne uurimisülesanne ja võib olla ka mitte eriti projektikõlbulik töö, ehkki tulemus oleks huvipakkuv. Muuseas ka selgitamaks, milline on senise ajalookirjutuse praktika vahekord näiteks teoreetiliste kontseptsioonidega.

Jörg Baberowski küsis kunagi provokatiivselt: kas ajaloolased vajavad teooriaid? ${ }^{11}$ Arutluse lõpus jõudis ta tõdemuseni, et on olemas teooriad ja on olemas jutustused (Erzählungen), ainult et teooriaid vajatavat selleks, et aru saada, et maailma hõlvamiseks pole olemas rahuldavat meetodit ning et need ei aitavat kaasa, et jutustada (aja)lugusid (Geschichten); teooriaid sildistavat need lood aga igal juhul. Eesti ajaloolased ei tohi kurta teooriakirjanduse kättesaamatuse üle. Terve plejaadi moodsa ajalooteooria- ja ajaloofilosoofia-alaste tekstide avaldamisega on ajakirjal Tuna olnud tähtis teesillutaja roll nüüdisaegse ajaloomõtte ja praktikate tutvustamisel Eesti lugejale. Veelgi enam on seda vaadet laiendanud sellised suured harivad tõlkesarjad nagu „Ajalugu. Sotsiaalteadused“ (25 raamatut!) ja „Avatud Eesti raamat". Võime veendunult väita, et suur osa ajaloofilosoofilisi ja -teoreetilisi tekste, mis on aastakümneid mõjutanud ajaloolist mõtlemist ja ajalookirjutuse praktikat läänemaailmas, on eestikeelses tõlkes kättesaadavad. Muidugi on omaette küsimus, milline on kogu selle kirjanduse mõju ajalookirjutuse praktikale Eestis. Postmodernistlikke teooriaid tutvustas 2008. aastal ajakirja Keel ja Kirjandus erinumber „Humanitaarteadused pöördes“, kuid pole teada, kas näiteks Eva Piirimäe kõigiti instruktiivne käsitlus keelelisest pöördest ${ }^{12}$ oli tarvilik parasjagu artiklit kirjutavale ajaloolasele. Tundub siiski, et ajalookirjutuse teooriad ja praktikad elavad oma elu ning ristuvad harva. Georg Iggers pani tähele, et on küll olemas postmodernse ajalookirjutuse teooriad - kuid kas on ka ajalookirjutuse postmodernsed vormid? ${ }^{13}$ Kindlasti on postmodernistlikust lähenemisest ajaloole õppida ja ongi õpitud, kuid traditsioonilise, narratiivse ajalookirjutuse väljavahetamist pole toimunud, vana ja uus liiguvad kõrvuti. Jaan Kaplinski kriitilisel tähelepanekul on osaliselt õigus, kui ta väidab, ,et viimased mitukümmend aastat on ühiskonnateadustes aina enam

\footnotetext{
${ }^{10}$ Kivimäe, J. Re-writing Estonian history? - National history and identity: Approaches to the writing of national history in the north-east Baltic region nineteenth and twentieth centuries. Ed. by M. Branch. (Studia Fennica: Ethnologica, 6.) Finnish Literature Society, Helsinki, 1999, 205-212.

${ }^{11}$ Baberowski, J. Brauchen Historiker Theorien? Erfahrungen beim Verfassen von Texten. - Arbeit an der Geschichte: Wieviel Theorie braucht die Geschichtswissenschaft? Hrsg. v. J. Baberowski. Campus, Frankfurt, New York, 2009, 117-127.

${ }^{12}$ Piirimäe, E. Keeleline pööre. - Keel ja Kirjandus, 2008, 8-9, 589-603.

${ }^{13}$ Iggers, G. G. Geschichtswissenschaft im 20. Jahrhundert. 2. Aufl. Vandenhoeck \& Ruprecht, Göttingen, 1996, 87.
} 
tegeldud teoreetiliste skeemide, isegi ideoloogiliste skeemide ehitamisega, neile tõestuste otsimisega, vähem konkreetse materjaliga“. ${ }^{14}$ Nii on näiteks postkoloniaalsuse teooriaga, mille „maaletoojad“ on enamasti kirjandusteadlased ja peaaegu üldse mitte ajaloolased. ${ }^{15}$ Eesti ajalookirjutuse seisukohalt on hoopis komplitseeritum rahvusliku (natsionaalse) ja rahvusülese (transnatsionaalse) ajaloo vahekord ning selle lahendused meie lähiaastate ajalookirjanduse praktikas. ${ }^{16}$ Nagu näitab hetkeseis, on uued teoreetilised ideed ja kontseptsioonid viimaste kümnendite jooksul kiiresti vahetunud; ,praktiline“ (s.o uuriv ja kirjutav) ajaloolane pole õieti jõudnud neisse süveneda ja sealt saadud tarku mõtteid katsetada, kui juba toimuvad uued ja moodsad ,pöörded“. Niisugune olukord - teoreetilis-praktiline kirevus - jääb ajalookirjutuses püsima ka järgnevail kümnendeil.

Ajalookirjutuse temaatilist arengut on võimatu ette näha, äärmisel juhul on võimalik midagi lisada desiderata kataloogi. ${ }^{17}$ Eesti päris oma ajaloolise mõtte seisukohast tuleks selgitada, kuivõrd see, mida me uurime ja millest kirjutame, kuulub mikro- või makroajaloo valdkonda. See pole imperatiivne ülesanne ja paljude uurimisteemade puhul tundub see olevat tarbetu, kuid Eesti ajaloo kui terviku mõtestamiseks siiski vajalik. Selle taga on peidus veel üks küsimus - kelle ajalugu? Pärast eesti talurahva ajaloo suurprojektide hülgamist on tegelikult vähe neid, kes sihipäraselt talupoja, eestlase ajalooga tegelevad. Eestlaste etnogeneesi uurimine ajaloolisel ajal on kummalisel kombel jäänud unustusehõlma. Ehk sünnib lähemas tulevikus ajalugu, arheoloogiat, antropoloogiat, ajaloolist keeleteadust, etnograafiat, asustuslugu jms siduv uurimisprojekt, mille eesmärgiks eesti rahva kujunemise uurimine. Sarnasel mõtteväljal heikleb veel teinegi suur ja sündsusetult lihtne teema „maa ja rahvas“ - mis sest, et see tooks kaasa vana asustusajaloo taassünni sümbioosis keskkonna- ja kliimaajalooga, mille uurimiseks tänapäeval on olemas suurepärased tehnilised (ja digihumanitaaria) võimalused. Ajaloouurimise strateegiatesse võiks teha asjaliku möönduse, et kui tahetakse instrumentaliseerida postkoloniaalseid suundi, siis vajaks see kaugema koloniaalse mineviku, sealhulgas vallutuste, kolonisatsiooni ja/või kultuuriülekande probleemide uut läbivaatamist. Kuivõrd siin nimetatud teemad on tulevikus jõukohased, on teadmata, ent ajaloolased ise on tähele pannud seaduspära, et ajalugu kirjutatakse iga kahekümne aasta järel uuesti ümber.

Eelmainitud arengute teoksaamisel on tähtis tingimus - millises keeles Eesti ajalugu ja ajalugu Eestis kirjutatakse. Süveneval ingliskeelestumisel on kaks tahku. Ühelt poolt võimaldavad ingliskeelsed publikatsioonid paremat teaduslikku kommunikatsiooni ja tagasisidet, teiselt poolt peab aga akadeemiline bürokraatiasüsteem eestikeelseid teadusartikleid ja uurimusi vähem väärtuslikeks. Vaatamata ametnike

${ }^{14}$ Kaplinski, J. Eesti, estoranto ja teised keeled. (Bibliotheca controversiarum.) Tallinna Ülikooli Kirjastus, Tallinn, 2020, 39.

${ }^{15}$ Vt nt Annus, E. Sotskolonialism Eesti NSV-s: Võim, kultuur, argielu. (Heuremata.) Tartu Ülikooli Kirjastus, Tartu, Tallinn, 2019.

${ }^{16}$ Väga hea sissejuhatav ülevaade: Tamm, M. Euroopa rahvuslik ajalookirjutus võrdlevas vaatluses. Tuna, 2017, 2, 128-138.

17 Väga hariv selles seoses on tutvuda kogumikuga „Debating new approaches to history“ (Ed. by M. Tamm, P. Burke. Bloomsbury Academic, London, 2019). 
ja keeleteadlaste väidetele, et eesti teaduskeelega on kõik kõige paremas korras, torkab silma, et eesti keel kaotab oma endist tähendust teaduskeelena ja eestikeelse erialasõnavara eest enam ei hoolitseta. Tartu Ülikoolis kaitstud ja kaitstavad doktoritööd on valdavalt ingliskeelsed, mitmel erialal lausa $100 \%$, eranditena paistavad silma kirjandusteadus ja ajalugu. Asjaolu, et Eesti vanema ajaloo oskussõnad pole adekvaatselt tõlgitavad inglise keelde, sest need on kujunenud saksa ja vene keele baasil, tundub olevat nagu hästi varjatud tõde. Marek Tamm nentis hiljaaegu, et me elame taas ühe kultuurikatkestuse ajal, sest aina vähem on neid, kes tunnevad 20. sajandi eelset Eestit, kes suudavad orienteeruda meie ladina- ja saksakeelses kirjapärandis. ${ }^{18}$ Tõsi, ladina keele õpetamine ülikooli tasemel on äärmuseni minimaliseeritud ning „vene keel on põlu all ja saksa keelt ei osata“ (nii väidab Malle Salupere ${ }^{19}$ ). Järelikult langeb praeguste ja tulevaste ajaloolaste õlgadele suur vastutus jätkata oma missiooni kõigi praeguste ja saabuvate majanduslike ja sotsiaalsete piirangute kiuste.

\section{MART KULDKEPP (University College London):}

Tulevikku ennustada ajaloolastele ei meeldi ning kaks aastakümmet tundub pikk aeg - eriti praeguses olukorras, kui raske on sedagi ette näha, mis tuleval sügisel saama hakkab. Erialane kiusatus on alustada pilguheiduga minevikku.

Eesti viimane suur historiograafiline murrang leidis aset 1990. aastatel ning selle sisuks oli rahvusliku ajalookäsitluse mitmesugune ärapäästmine ja taaselustamine, mida võimaldas nõukaaegse ideoloogilise kontrolli lakkamine. Sel ajal oli ka avalikkuse tähelepanu Eesti akadeemilise ajaloouurimise vastu küllaltki intensiivne. Järgnenud perioodi on seevastu iseloomustanud pigem vaikne ja rahulik erialasisene areng, mille tagajärjeks on olnud järjest süvenev lõhe rahvusvahelistuvate-professionaliseeruvate ajaloolaste (nn punaprofessorid ja selartlased) ning 1990. aastatesse pidama jäänud populaarse ajalooteadvuse vahel, mis kangekaelselt keeldub oma anakronistlikke seisukohti revideerimast. Samasugune lahkukasvamine jätkub ka praegu.

Minu enda kui samuti punaprofessori ja selartlase seisukohalt seisneb viimase paarikümne aasta mälulahingute õppetund eelkõige selles, et eesti ajalugu on rahvusteadus. Või õigemini teistpidi: eesti rahvus on ajaloorahvus, mida poleks sel kujul olemaski, kui eestlasliku ajalookäsitluse lahknemine baltisaksa omast poleks aset leidnud juba rahvusliku ärkamise ajal, ammu enne professionaalse ajalooteaduse teket Eestis. Identiteeti loovad-kinnitavad narratiivid, käigu need muistse vabadusvõitluse või Teise maailmasõja kohta, on eesti rahvusluse pärusvara tänini. Seetõttu tahaksin loota, et edaspidi üks jõudsamalt arenevaid valdkondi Eesti ajalooteaduses ongi just mineviku (aga ka minevikuloome) uurimine eesti rahvuslusega seoses ja selle seisukohalt. Nüansirikkalt tunnetada ja mõtestada ajaloo keskset rolli eestluse jaoks on ülesanne, millest lähtuvalt püüan skitseerida ka järgneva uurimisprogrammi.

${ }^{18}$ Tamm, M. Pildikesi kadunud maailmast. - Postimees, 11.01.2019

${ }^{19}$ Salupere, M. Eesti rahva ja Eesti Üliõpilaste Seltsi auvõlg Jannseni ees jäi lunastamata. - Keel ja Kirjandus, 2020, 6, 539. 
Eesti ajalookirjutuse põhimõttelisest rahvuslikkusest on tulenenud selle keskendumine väikesele hulgale rahvuslikult oluliseks peetud pöördelistele sündmustele. Lähiajalooga piirdudes võiks nimetada Eesti iseseisvumist, Vabadussõda, ehk ka Konstantin Pätsi riigipööret ja nn vaikivat ajastut, iseseisvuse kaotust, Teist maailmasõda, stalinismi ja sovetiseerimist ning iseseisvuse taastamist. Rahvusliku ajalookirjutuse üks tähtsamaid ülesandeid on selle nimekirja täiendamine-täpsustamine ja revideerimine-mitmekesistamine.

Esiteks leidub teadmata arvul teisi, nende üldtuntud pöördepunktide taha tihti varju jäänud sündmusi, mille juurde oleks mõtet rohkem ja süstemaatilisemalt tagasi minna. Võimalike teemade seas on 1905. aasta Vene revolutsioon ja selle mõju Eesti poliitilise iseteadvuse tekkele, samuti Esimene maailmasõda koos 1918. aasta Saksa okupatsiooniga kui Eesti riikliku iseseisvuse ja Vabadussõja eellugu. Osa võimalikest varjujäänud sündmustest on nii vähe uuritud, et neile oleks praeguse seisuga raske isegi osutada (kas „Vietnami sõja mõju nõukogudevastastele protestiliikumistele ENSV-s" võiks olla perspektiivikas uurimisteema?); teistest kasvavad välja kontrafaktuaalsed küsimusepüstitused („Milliseks oleks kujunenud Eesti saatus, kui Stalini surma järel oleks võimule tõusnud Beria?").

Teiseks tuleb eespool toodud sündmuste juures leida uudseid momente vaatepunkti muutmise teel. Üks võimalus on läheneda teemadele laiemas kontekstis: rääkida Eesti iseseisvumise asemel tsaarivõimu ajajärgu lõpust Eesti- ja Liivimaal; käsitleda Vabadussõda kui Eesti riigi osalemist bolševismivastases ühisrindes aastatel 1918-1920. Teine võimalus on näha sündmusi mittetraditsiooniliste osalejate vaatevinklist, nt 1930. aastate teist poolt Pätsi-vastase opositsiooni seisukohalt või iseseisvuse kaotust juunikommunistide pilgu läbi. Sõja- ja poliitilisele ajaloole pakuvad täiendust mitmesugused sotsiaal- ja kultuuriajaloolised käsitlused. Uurimisteemadena võiks kõne alla tulla muu hulgas „Teise maailmasõja aegne igapäevaelu ja toimetulekustrateegiad“, aga miks mitte ka „Sotsiaalse kontrolli mehhanismid, hüved ja hirmud, mis suunasid stalinistlike kuritegude toimepanijaid“ või „Mõttemustrid, mis ei lubanud välismaailmal külma sõja lõpu ajal Nõukogude Liidu nõrkust lõpuni tunnetada“.

Väga suur eelis, mis uudseid vaatenurki soosib ning mis on olemas tänapäeva Eesti ajaloolastel võrreldes vanemate põlvkondadega, on allikate pretsedenditult hea kättesaadavus ja arhiivide avatus. Viimane sõltub tihti küll sellest, kas uurimistöö tegemiseks leidub rahalisi vahendeid, ent tööd uurimissaalis saab mingil määral (ja järjest enam) asendada digihumanitaaria pakutavate võimalustega. Eesti Rahvusarhiiv on arhiivimaterjalide digiteerimise poolest maailmas esirinnas ning Eesti Rahvusraamatukogu Digari andmebaas on pannud vanu ajalehti lugema vägagi suure hulga inimesi, kes muidu selle pealegi poleks tulnud.

Eriti perspektiivikad tunduvad mulle mitmesugused ühisloomeprojektid, mis lubavad allikatest kätte saada seni kasutamata andmemassiive, nagu Esimeses maailmasõjas osalenud Eesti sõdurite nimed ja teenistuskäigud või vallakohtute materjalides leiduv mitmekesine andmestik 19. sajandi Eesti maaelu kohta. Samamoodi nagu ornitoloogid vajavad linnuvaatlejaid, võiksid ajaloolased tunnistada, et nad vajavad ajaloohuvilisi, keda vähemalt potentsiaalselt leidub ilmselt rohkemgi. 
Ühisloomevõimekust ja üldse avalikkuse kaasatust ajaloo uurimisse tuleks kindlasti edasi arendada.

Avalikkuse huvist johtub ka ajaloolise sisuga lugemismaterjali nõudlus, mis on jätkuvalt suur. Hea näide sellest on klantsajakirjad, mida Eesti turul on mitmeid ning milles Eesti ajaloolased võiksid ise rohkem avaldada, selle asemel et nende väljaannete toimetajad ilmunud publikatsioonide põhjal referaate koostaksid ja neid pildimaterjaliga varustatult ära trükiksid. Tugev praktiline ja avalikkuse poole suunatud nägu võiks olla eriti mälu-uuringutel, mille alla kuuluvad mitmesugused monumendi- ja muuseumiuuringud. Interdistsiplinaarseid ühisteemasid, mis laiemat tähelepanu köidaks, oleks ajaloolastel leida ka folkloristide, etnoloogide ja kirjandusteadlastega.

Lõpuks ei saa jätta mainimata, et ajaloo olulisus Eesti ühe kesksema rahvusteadusena peaks kajastuma ka teadusrahastuses. Ajaloouurimisel pole mitte ainult teaduslik, vaid ka poliitiline tähtsus. Vladimir Putini hiljutine artikkel Teise maailmasõja teemadel näitab selgelt, et informatsioonilise enesemääramise lahingutandril ollakse jätkuvalt sügavale positsioonidele sisse kaevunud. ${ }^{20}$ Ei tohi aga unustada, et kuigi ajalugu on omamoodi relv, peab see relv olema vahe, mitte nüri: ajalugu on vaja professionaalselt uurida, mitte sellest kõhutunde ajel mõelda või kirjutada, ning enne lahingusse minekut peab luure olema tehtud. Eesti inimene on üldjuhul tugeva rahvusliku identiteedi ning seetõttu ka tugeva ajaloonärviga. See asjaolu paneb ajaloolase mõnikord keerulisse olukorda, samas aga osutab ka tegemata tööle. Saagu see töö edaspidi tehtud.

\section{ANU MAI KÕLL (Södertörni Ülikool):}

Eesti ajalooteadus on pärast Eesti iseseisvuse taastamist arenenud kahes eri suunas. Esimene on riigikeskne, poliitiline ajalugu, deutsche historische Schule vaimus. Seda suunda viljeletakse endiselt mujalgi maailmas, kuid see on minetanud oma juhtiva positsiooni. Poliitilise ajaloo metodoloogia vallas on Eestis vähe tehtud, teistes maades on tulnud käibele mitmed uued vaatlusviisid, mis riigi ülemise kihi kõrval käsitlevad ka madalamaid tasandeid, nagu kohalik valitsemine ja eri institutsioonid. Teine suund algab elulugude uurimisega, see tähendab isikukeskse ajalooga, ja on arenenud mälu-uuringute suunas. See on kooskõlas mälu-uuringute üldise populaarsusega maailmas, kus aga isikukeskne perspektiiv on vaid üks teiste seas. Muidugi, selline üldpilt on väga lihtsustav, leidub ka ohtralt erandeid. Kuid julgen siiski väita, et need kaks suunda on Eestis esiplaanil, kusjuures omavahel on need pigem vastanduses, mitte dialoogis. Esimene on veel valdavalt meesuurijate pärusmaa, teises tegutsevad peamiselt naisuurijad.

Mõlemas suunas tegeldakse mõistagi palju postsovetliku olukorraga, suure ajaloolise pöörde lahtimõtestamisega. Ent mis saab edasi? Järgmine uurijate põlvkond

${ }^{20}$ Putin, V. The real lessons of the 75th Anniversary of World War II. - The National Interest, 2020, 168, loetav veebis: https://nationalinterest.org/feature/vladimir-putin-real-lessons-75th-anniversaryworld-war-ii-162982 (02.08.2020). 
pole Nõukogude Liidus enam elanud. Arvata võib, et nende huvid liiguvad mitmes eri suunas, kus on üha olulisemad ka keskkond, ühiskondlikud olud, soolised vahekorrad ja majandus. Samas koolitab neid endiselt vanem põlvkond ja juhendajatest tingitult on uute teemade valik osaliselt piiratud. Tuleb ka silmas pidada, et Eesti on väike riik ja akadeemilise ajaloo suur killustumine, nagu suuremates riikides kombeks, ei oleks siin soovitav.

Minu ennustus ja soov edaspidiseks on, et Eesti ajalooteadus liigub üha enam üle riigi ja rahvuse piiride, samas nendega seost kaotamata. Eesti koht maailmas peaks olema tähtis ajalooline uurimisteema. Sellega ei pea ma silmas üksnes Baltimaade omavahelisi suhteid või suhted Venemaaga, samuti mitte Eesti diplomaatia uurimist. Eesti territooriumi üle on suuremad naabrid alati tülitsenud, Baltimaad on nagu omalaadi Põhja-Euroopas asuv Lähis-Ida piirkond, kus suured religioonid, rahvused, keelegrupid, poliitilised ja ideoloogilised süsteemid on pigem kokku põrganud kui üheks sulanud.

Euroopa ajalugu jaguneb tänapäeval tihti kaheks pooleks: üks, mis jääb seisma Poola piiril, ja teine ehk Ida-Euroopa ajalugu. Kui ma veel ülikoolis ajalugu õpetasin, siis otsisin tudengite tarbeks kaua sobivat üldkäsitlust, mis haaraks mõlemat poolt. Lõpuks leidsin inglise ajaloolase Mark Mazoweri teose „Dark continent“ (1998), mis käsitleb paraku vaid eelmist aastasadat. Siiski annab selle raamatu üleeuroopaline haare ja soov vaadata juhtunut mõlemalt poolt palju juurde nii LääneEuroopa kui ka Kesk- ja Ida-Euroopa ajaloole.

Poliitilises ajaloos on laiem kontekst eriti tähtis. Mida tähendab tänapäeva Eestile see, et Peeter Suur rajas 18. sajandi algul Peterburi linna Soome lahe kõige kaugemasse serva? Eelmisel sajandil määras näiteks Leningradi asukoht ja Eesti positsioon Saksamaa ja Venemaa vahel väga palju. Siiski on Eesti ajaloolased kuidagi Saksa poole ära kaotanud, see tuleks kindlasti uuesti esile tuua. Nii saaks usutavasti selgitada sedagi, millel põhinevad mõned tänapäeva konfliktid Euroopa Liidus. Kesk- ja Ida-Euroopa ning Lääne-Euroopa jäid Teise maailmasõja järel lahku. Tulemuseks pole üksnes see, et Lääne riigid ei saa päriselt aru, mis 20. sajandi teisel poolel Saksamaast ida pool juhtus. Ka eestlased ei ole päriselt mõistnud, mis LääneEuroopas juhtus, miks peeti Hitlerit põhivaenlaseks ja miks oldi nõus, isegi kui vastumeelselt, tegema koostööd Staliniga. Ka Saksa okupatsiooni aega Eestis tuleks põhjalikumalt uurida, see oleks ühtlasi hea võimalus rahvusvaheliseks koostööks nii Kesk- ja Ida-Euroopa kui ka Lääne-Euroopaga.

Poliitika kõrgsfääri kõrval leidub palju huvitavat ka allpool, näiteks on nii kohalik poliitika kui ka kohalikud institutsioonid huvitavad ja inimeste argielule lähemal (haridus, tervishoid, maksud, õigussüsteem, tsensuur, haldus jne). Nende teemade kohta leidub arhiivides rikkalikult materjali, nii et tööd jätkuks paljudele. Selliseid ühiskondliku elu konkreetseid aspekte on võimalik võrrelda teiste maade omadega, see on täpsem ja lihtsam, kui võrrelda ühiskondi tervikuna. Säärane võrdlev analüüs aitaks paremini mõista Eesti eripära, näiteks võrdluses Rootsi või Saksamaaga.

Ajaloouurimise metodoloogiat saab uuendada, pöörates suuremat tähelepanu uuringu ülesehitusele ja esitades uusi küsimusi oma uurimistöö raamide kohta: miks 
ja kuidas teema on valitud, kuidas probleem on sõnastatud, milliste võtetega seda uuritakse jne. Allikakriitika on endiselt väga oluline, ent senisest paindlikum ja mitmekesisem, küsides, kelle häält uurija allikas kuuleb. Vana kvalitatiivsete ja kvantitatiivsete meetodite eristus kehtib jätkuvalt, kuid uusi võimalusi tuleb pidevalt juurde. Torkab silma, et kvantitatiivne ajalugu on viimasel ajal tagaplaanile jäänud, vaatamata asjaolule, et arvutite areng on tugevdanud selle potentsiaali. Oleksin üllatunud, kui seda tulevikus enam ei kasutataks. Lisaks kirjeldavatele statistilistele meetoditele võimaldab kvantitatiivne uurimine testida täpsemalt mitmesuguseid uurimishüpoteese. Analüüsida saab mahukaid kirjalike allikate andmebaase, nagu näiteks kirjavahetused, kollektiivsed biograafiad jms. Viimaks võimaldab arvutitehnoloogia kasutada ajaloo uurimisel uusi ruumi-analüütilisi meetodeid, mis tunduvad väga perspektiivikad.

Viimased kolmkümmend aastat on olnud poliitiliselt oluline näidata Eesti riigi ajaloolist järjepidevust. Sellega on aga kõik suuremad murrangud ja võimuvahetused tagaplaanile jäänud. Leian, et murrang on Eestile siiski iseomasem kui järjepidevus. Kohalikud võimuvõitlused on pikemas vaates osa loost, kuidas Eesti identiteet on läbi aastasadade arenenud ja saanud lõpuks üheks läänemaailmaga. Ajalooliselt tähendab see mõtteloo, uskumuste, väärtuste, majanduslike, humanistlike ja ühiskondlike ideede (sh soolise vahekorra) uurimist. Kuidas vaated lastele, tööle, haridusele, võrdsusele ja hierarhiatele on aegade jooksul muutunud? Selle kõige uurimisega tegeleb kultuuriajalugu, mida võib pidada tänapäeva ajalooteaduse üheks kõige populaarsemaks haruks.

Kuid juba on kultuuriajaloos mõjukad postmodernne teooria ja sotsiaalne konstruktivism kriitika all. Kuidas kultuuriajalugu tulevikus areneb? Praegu saab sellest kõige paremini aimu töödest, kus mõtlemisviise, väärtushinnanguid ja elustiili uuritakse konkreetsete pisiasjade näitel, olgu selleks tarbimine, mood, matmiskombed, elutarkused raamatutes ja nõuandluses. Ühe äärmusliku näitena võib välja tuua uurimistöö sellest, kuidas meeste näokarvade hooldamine aja jooksul on muutunud või milliseid kehakarvu on pidanud naised ära ajama või peitma. Need on pisiasjad, mille uurimine näitab, kuidas on muutunud ajas arusaamad kehast ja seksuaalsusest ning isikliku ja avaliku elu vahekord.

Mäluga seotud keerulised teemad viivad tahes-tahtmata küsimuste juurde migratsioonist ja põgenemisest. See suur temaatika on juba uurimise all, ent vajab endiselt avardamist, sh migrantide ja põgenike uue olukorra (sh nende tagasituleku) käsitlemist. Mina ootan endiselt suuremat uurimust Nõukogude Liidu aegsest migratsioonist, mis sageli polnud vabatahtlik, sh ka Eesti suunas, ja mis käis lainetena majandusliku arengu järel. Mul on ikka veel kahju, et meie sellel teemal koostatud uurimisprojekt ei saanud 1990. aastate lõpus Euroopa Liidu rahastust. Vähemusgruppide edukam lõimimine vajab kindlasti teadmist ka nende ajaloolisest taustast.

Kokkuvõtteks võiks minu arvates Eesti ajalooteaduse edasine suund olla üle riigipiiri astumine. Senisest suurem tähelepanu suhetele välismaailmaga aitaks suurendada selgust ka sisemises arengus. Üle piiri kiigata ja keerulist võrdlevat vaatepilti arendada, see oleks minu hinnangul eriti soovitatav. 


\section{KRISTO NURMIS (Stanfordi Ülikool):}

Johannes Semperi päevaraamatust leiab ebatavalise sissekande 26. detsembrist 1965. Tollal juba 73-aastane ,juunikommunist“ kirjeldab kohtumist ENSV Kirjanike Liidus kahe Moskvast saabunud ideoloogiatöötajaga, kes küsitlesid liidu juhtkonda rahvusküsimuse seisust Eestis: „Et kas on see aktuaalne küsimus, olevat ju Eestis praegu $20 \%$ venelasi." See moskvalaste kommentaar vallandab laviini. Kirjanikud annavad tunnetele vaba voli ja valavad külalised üle kaebustega sellest, kuidas kooli astuvate vene laste arv ületab eesti omi, kuidas kirjanikud peavad venelaste kujutamisel panema neile eesti nimed, kui neil juhtub olema negatiivseid loomuomadusi, ja kuidas rahvaste sõprusest üldse räägitakse ,ainult abstraktseid sõnu“. Moskva ideoloogiatöötajad selgitavad kirjanikele, et Eestisse saabunud venelased on „kultuuriliselt kohalikest madalamal järjel“ ja et see on just nende - kirjanike ülesanne hoolitseda sisserännanute taseme tõstmise eest. Selle peale käratanud Uno Laht: „Te pole nii tähtsad ninad, et saaksite siin selliseid küsimusi lahendada.“21

Seda sissekannet esimest korda lugedes jäin mõtlema, kui vähe me ikka veel tunneme nõukogude perioodi ajalugu. Kui kasinalt tehakse meil võrdlevat ajalugu ja kui harva seostatakse uurimistulemusi rahvusvaheliste vaidlustega. Kirjutades neid ridu küll Räniorus, ei hakka ma siinkohal müütama metodoloogilisi trende süvaajaloost, posthumanismist või ulmelisi digihumanitaaria võimalusi. Selle asemel püüan tõmmata tähelepanu fundamentaalsematele ja realistlikumatele uurimisküsimustele, mida Eesti ajalookirjutuses võiks senisest rohkem näha. Semperi päevikusissekandega tahtsin osutada ühele sellisele põhjapanevale teemale, asjaolule, et meil puudub endiselt selge ülevaade Moskva rahvuspoliitika konkreetsest sisust ja selle toimemehhanismidest, sellest, kuidas erinevad nõukogude instantsid rahvuspoliitikat juhtisid, mõtestasid ja kontrollisid. Semperi sissekanne tõstatab mitu olulist küsimust nõukogude etnopoliitilisest ruumist ja hierarhiatest, nõukogude arusaamast modernsusest, Eesti kommunistide muutuvast minapildist ning reaalse sotsialismi ehitamisega kaasnenud frustratsioonist ka selle eestvõitlejate seas. Semperi päevikusissekandes ei kritiseeri nõukogude rahvuspoliitikat mitte dissidendid või uue põlvkonna kontrakultuur, vaid kõige ,punasemad“ kohalikud kirjanikud, endised stalinistid. Moskva ideoloogiatöötajate arusaam eesti kultuuri arendavast mõjust sisserännanutele paneb seevastu küsima, kas eestlane oli nõukogude ajal üksnes okupeeritud ja „koloniseeritud“ rahvusgrupp. Kas on võimalik et teda nähti hoopis kultuurikandjana, koguni kommunistlikku süsteemi „moderniseeriva“ jõuna?

Meil on palju kirjutatud Eestist ja Baltikumist kui „nõukogude Läänest“, anomaalsest regioonist, mis tegelikult justkui ei kuulunudki Nõukogude Liitu. Ühelt poolt on see isegi õigustatud lähenemisnurk. Ka parteijuhtkond nägi eestlastes, lätlastes ja leedulastes „,noori“ nõukogude rahvaid, kes liitusid „rahvaste perega“ hilja ja ettevalmistuseta. Teisalt võib aga küsida, kas Baltikum oli tingimata normivälisem Nõukogude Liidu piirkond kui näiteks Kesk-Aasia, Kaug-Ida või Siber, või isegi metropolid Moskva või Leningrad. Lähemal vaatlusel selgub, et unitaarne nõukogude riik kirendas oma igapäevaelus anomaaliatest ja sotsiaal-kultuurilistest eri-

\footnotetext{
${ }^{21}$ Semper, J. Päevaraamatud. Toim K. Ligi. Ilmamaa, Tartu, 2013, 384-385.
} 
päradest. Ja siin leidub ilmselt ka üks võimalik Eesti nõukogude-uuringute tulevikuperspektiiv: analüüsida Eestit ja Baltikumi võrdlevalt osana nõukogude üle Euraasia ulatuvas ühiskondlikus võrgustikus. Üksnes võrdlev meetod ja rahvusüleste sidemete silmaspidamine aitab meil mõtestada seda, mida pidada Eesti tollases arengus ainulaadseks ning milles näha üldist nõukogude või üle-euroopalist või globaalselt ühist trendi. Eesti ajaloolastel oleks lisada huvitavaid uusi vaatenurki juba niisugustele palju diskuteeritud teemadele nagu Nõukogude Liidu rahvuspoliitika, subjektsus, demograafia ja ühiskonna struktuur, Teise maailmasõja pärand sõjajärgses igapäevaelus, nõukogulik moderniseerimisdiskursus ja sellevastane reaktsioon - mitte vähem modernne vabatahtlik aktivism (muinsus- ja looduskaitseliikumine, üliõpilasringid jms). ${ }^{22}$

Võrdlev meetod aitaks Eesti ajaloolastel laiendada oma vaatenurki üleliidulisele, rahvusülesele ja miks mitte ka globaalsele tasandile, ning seega osaleda edukalt ka rahvusvahelisel areenil. Rahvusvahelisel tasandil mõtestatakse Nõukogude Liidu ajalugu endiselt üpris Vene-keskselt, kus Moskvat, Leningradi või mõnd Vene provintsi uurivad ajaloolased üldistavad oma tulemused enesestmõistetavalt nõukogude „tsivilisatsioonile“ tervikuna. Mittevene regioonide ja rahvuste uurijatele jääb justkui üksnes regiooniajaloo ja etnilise nüansi selgitamine. Kuid viljakas võib olla ka vastupidine suundumus. Nagu mõned ajaloolased on juba näidanud, saab mittevene regioonide materjali põhjal kirjutada mõjukaid ja veenvaid teadustöid ka terve Nõukogude Liidu kohta. Ajaloolased kasutavad üha enam Eesti, Balti ja Ukraina vabu arhiive uurimaks teemasid, mida Vene arhiivid ei võimalda (olgugi et jutud Vene arhiivide suletusest on sageli veidi liialdatud). Näiteks avaldas Toronto Ülikooli ajaloolane Lynne Viola 2018. aastal monograafia Stalini suurt terrorit korraldanud NKVD ohvitseride represseerimisest; ta kasutas selle kirjutamiseks Euromaidani järel avanenud Ukraina arhiive. ${ }^{23}$ Grinnelli kolledži ajaloolane Edward Cohn on kirjutanud huvitavaid artikleid KGB ,profülaktilisest“ vestlusmeetodist poliitilises „kasvatustöös“ ja ühiskondliku korra hoidmisel; ta tugineb peamiselt Leedu, aga ka Eesti ja Läti, julgeolekumaterjalidele. ${ }^{24}$ Selleks, et Eesti noored ajaloolased suudaksid rikastada ajalookirjutust ,,suurtes küsimustes“ (ja taibata, kui väärtusliku materjali otsas nad tegelikult istuvad), nõuab oma panust (nt historiograafiliste

\footnotetext{
${ }^{22}$ See kõik ei tähenda muidugi Eesti ajaloo pikema perspektiivi ja sotsiaal-kultuurilise kontinuiteedi ignoreerimist. Vastupidi, eesti rahvuse formeerumise n-ö pika kaare uurimisel oleks väga viljakas analüüsida lisaks nõukogude korra põhjustatud katkestusele ka nõukogude perioodi loovat ja kureerivat rolli nüüdse eesti rahvus(lus)e kujunemisel. Uurimise all poleks siin üksnes rahvuslus kitsas mõttes, vaid see, kuidas ühiskondlikud vaated, hoiakud ja käitumisviisid on muutunud. Kuidas teisenes (või jäi samaks) tavainimese arusaam näiteks majandusest, omandist, perekonnast, soolisusest, seksuaalsusest, töökultuurist, vaba aja veetmisest, sotsiaalsest õiglusest, linna-maa ja noorte-vanade vahekordadest, inimese-looduse ja riigi-kodaniku suhetest, tehnoloogiast ja progressist.

${ }^{23}$ Viola, L. Stalinist perpetrators on trial: Scenes from the Great Terror in Soviet Ukraine. Oxford University Press, New York, 2017.

${ }^{24}$ Cohn, E. A Soviet theory of broken windows: Prophylactic policing and the KGB's struggle with political unrest in the Baltic republics. - Kritika: Explorations in Russian and Eurasian History, 2018, 19, 4, 769-792; Cohn, E. Coercion, reeducation, and the prophylactic chat: Profilaktika and the KGB's struggle with political unrest in Lithuania, 1953-64. - The Russian Review, 2017, 76, 2, 272-293.
} 
erikursuste näol) ka Eesti õppejõududelt, kes aitaksid tudengitel neis küsimustes ja debattides paremini orienteeruda.

Eesti ajalookirjutus on muu läänemaailmaga võrreldes noor ja hõre. Sellega kaasnevad omad puudused, aga ka olulised eelised. Hõredal uurimisväljal puudub konkurents, millest tuleneb metodoloogiline laiskus, pealiskaudsus ja üksiuitlemine, debati nappus. Kuid hõredus avab ka võimalusi, eriti võrreldes suurriikide ajalookirjutusega. Noored ameerika ajaloolased peavad leidma oma niši äärmiselt küllastunud uurimisväljal. Nad seisavad vastamisi paarisaja aasta vanuse tiheda ja järjepideva historiograafiaga, mida toodetakse reaalajas sadades ülikoolides (minu koduülikooli raamatukogus moodustavad monograafiad ainuüksi president Franklin D. Rooseveltist kolm kuuerealist riiulimassiivi, ja need on üksnes avariiuli ühikud). Eesti ajaloolastel seevastu on võrreldamatult rohkem mänguruumi avastada uusi algallikaid, valida oma lähenemisnurk ja alamdistsipliin ning olla selle pioneer. Kui noored ameerika ajaloolased saabuvad peolauda hiliste külalistena, kus paremad palad on juba söödud, siis noored eesti ajaloolased saabuvad peole, kus pole laudki veel kaetud. Iseasi on, kas uurimata teemade ja arhiivimaterjalide küllus kandub üle ka avalikule huvile ja noorte karjärrivõimalustele. See küsimus kuulub aga juba omaette valusasse teemasse teadusrahastusest ja praeguste „tähtsate ninade“ poliitilistest valikutest.

\section{KRISTJAN TOOMASPOEG (Salento Ülikool):}

Kummalisel moel pole ajaloolased tavaliselt kuigi head tuleviku ennustajad ja Eesti teadlastel pole kahtlemata mingit vajadust oma homse päeva kavandamiseks kusagilt kaugelt Vahemere äärest tulevat „tarka juttu“ kuulata. Aga teema on põnev ja andis mulle hea põhjuse ennast meie uuema ajalookirjutusega paremini kurssi viia. Samas on „võõra“ pilk vahel teravam, sest, nagu öeldud, mida kaugemalt vaatad, seda paremini paistab silma see, mis suur ja määrava tähtsusega, ning igasugused tüli ja segadust tekitavad pisiasjad jäävad vaateväljast kõrvale. Luban siis endale paar mõtisklust meie ajalooteaduse tuleviku teemal, piirdudes aga üsna rangelt omaenda erialaga ehk siis keskaja ajalooga.

Aluspõhi on hea ja tugev. Vanemate põlvkondade mehed ja naised, need, kes juba enne 1991. aastat uurimistööd tegid, on veel toeks. Vanal ajal rajatu on alles ja säilitab oma taset, alates arheoloogiast ja lõpetades pärimuskultuuriga. Uus põlvkond on säilitanud vanad sidemed idaga, lõimudes samal ajal läänega, ja enam pole vajalik, nagu läinud sajandil, valida Vene, Skandinaavia, Saksa või kohaliku rahvusliku suundumuse vahel: ajaloo uurimine on rahvusvaheline ja käib inglise keeles. On tõsi, et meie ajaloolaste arv on väike. Kiire arvutuse põhjal leian keskajaga ametipäraselt tegelejate hulgaks poolsada meest ja naist, aga nendest ainult ligi viisteist on sellele erialale täielikult pühendunud. Ajaloolaste piiratud arv - see kehtib ka uusaja ja uusima aja asjatundjate puhul - ei tekita aga muret olukorras, kui meie ajaloolased kuuluvad rahvusvahelistesse võrgustikesse ja paljud ,välismaalased“ tegelevad Eesti ajaloo uurimisega. Meie ajalookirjandus oleks palju vaesem ilma 
selliste asjatundjate kaastööta, nagu on Karsten Brüggemann, Alan Murray või Matthias Thumser. Samas on suudetud muuta Eesti või Liivimaa või Baltimaade ajalugu rahvusvaheliseks uurimisteemaks, olgu siis tegemist ristisõdade või mentaliteedija kultuuriajalooga.

Mitte kõik ei ole täiuslik ega saa seda ka kunagi olema. Meie ajaloolased seisavad samasuguste raskuste ees nagu nende ametikaaslased pea kõikjal mujal. „Eesti keskaja" köite ilmumise järel tekkinud avalik vaidlus näitas, et on tekkinud lõhe elukutseliste ajaloolaste ja laiema haritud avalikkuse vahel. Nagu mujalgi, kirjutavad ka eesti ajaloolased oma tähtsamad tööd inglise või mõnes muus võõrkeeles, pakkudes kohalikule lugejaskonnale enamasti üldise ja hariva sisuga või kohalikke mälestisi tutvustavaid üllitisi. Tegemist on ohtliku arenguga, mis võib ajalookirjutuse kohalikust kultuurielust välja viia. Teine probleem on projektipõhine teadustöö, mille mõttekus humanitaarvallas tekitab tõsiseid kahtlusi. Iga uurimisteema peab olema sildistatud ja paigutatud mõnda kõlava nimega lahtrisse, ning lõppkokkuvõttes, täpselt nagu nõukogude ajal, on olemas ,perspektiivikad“ ja ,perspektiivitud“ teemad. Sildid on läikivad ja peegeldavad avalikku arvamust. Enam ei tohi barbareid süüdistada Rooma riigi hukus, vaid tuleb mõelda germaanlaste ja roomlaste üheskoos loodud keskaegsele tsivilisatsioonile. Samamoodi on minu hinnangul Liivimaa 13. sajandi ristiusustamise ja vallutamise praegune seletus liiga „pehme“: mis on hea pikemas perspektiivis, ei pruugi seda olla toimumise ajal.

Aga tuleme nüüd foorumi teema juurde tagasi ja üritame ette näha, kuhu Eesti ajalookirjutus lähimate aastakümnete jooksul liigub või liikuma peaks. Praegu on Eesti ajalooteadus veel nagu mängueas laps, kes näeb pidevalt midagi huvitavat ja mõistatuslikku, millele peab kohe selgituse leidma. Miks olid Eesti kihelkonnad nii suured? Miks meil oma katoliku pühakuid ei ole? Kes asutas Tallinna linna? Küsimused on olulised ja nõuavad vastuseid ning praegu olukorda seirav 1970. aastatel sündinud ajaloolaste põlvkond leiab ennast küllap tihti samast olukorrast kui Sten Karling, kui ta noore mehena esimest korda Tallinna Pühavaimu kirikusse astus: midagi on siin teistmoodi ja kuidagi valesti, aga ei tea veel miks.

Eesti keskaja uurimisele on iseloomulikud kaks suundumust, mis kahtlemata järgimist leiavad ja veelgi süvenevad. Esiteks toimib koostöö ajaloolaste, arheoloogide, arhivaaride, kunstiteadlaste ja pärimusteadlaste vahel. See tundub loomulik, aga pole seda üldsegi mitte: näiteks teisel pool Alpe, kus mina töötan, on selline koostöö suhteliselt haruldane. Igal rahval on oma eripära: prantsuse ajaloolased on ka geograafid ja nende teosed algavad pikkade ja põhjalike maateaduslike kirjeldustega, Saksamaal on ajalugu aga seotud rohkem filosoofiaga laias mõistes. Teiseks on Eestis huvitav olukord, kus arhivaalidega hästi kaetud 16. sajandit uurivad korraga nii uusaja kui ka keskaja asjatundjad. Siin saaks tuua võrdluse Itaaliaga, kus hoopis 15. sajand, humanismi ajastu, on omaette uurimisvaldkond, millega tegelevad quattrocentisti, keda võiks määratleda kui muteerunud medieviste. Meie ajalookirjanduses on aga, vastupidi, üleminek keskajalt uusajale kuidagi sujuvam.

Nii et meie ajaloolased on vabamad nii ajas kui ruumis ega pea ennast sulgema kitsastesse kastidesse. Samas on tulevik paratamatult rännumeeste päralt: oma paari 
õppetooliga ei saa Eesti kõigile tulevikulootusi jagada; jätame siinjuures puudutamata teadustöö rahastamise teema, mille üle võiks väga pikalt arutleda. Juba ammu on välismaal tekkinud tüüpkujutis noorest Eesti ajaloolasest, kes räägib võõrkeeli ja oskab nii seltskonnas arutleda kui ka seinale krohvi visata, veidi nagu Kristjan Jaak, veidi Felix Krull. Need noored mehed ja naised alustavad oma teaduskarjääri välismaal ja on põhjust arvata, et meie ajalooteaduse side rahvusvahelise teaduskeskkonnaga aja jooksul veelgi süveneb. See tähendab, et „meie“ ajalugu vaadeldakse jätkuvalt laiemas laastus, lähtudes suurtest teemadest.

Vaadates praegu uuritavaid või uuritud teemasid, saab eristada need, mida on käsitletud palju, nagu näiteks 13. sajandi ristisõda (enam ei ole kombeks rääkida muistsest vabadusvõitlusest) ja Liivimaa kui ääremaa roll, ka suhteid Vene vürstiriikidega on väga põhjalikult vaadeldud, loomulikult ka 16 . sajandi usupuhastust. Eesti ajaloolased on palju tähelepanu pööranud igapäevaelule, toidule, riietusele ja muule argisele. Teised teemad, nagu näiteks mungaordud või piiskopid ja nende kapiitlid, on küll käsitlemist leidnud, ent vajavad suuremat kokkuvõtvat uurimust.

On üsna tõenäoline, et järgnevate aastakümnete jooksul suudetakse kõik Eesti pinnal leiduvad keskaja ajaloo allikad ühtsesse nimekirja kanda ja ära digiteerida. Suur osa sellest tööst on tänu Tallinna Linnaarhiivile ja teistele mäluasutustele juba tehtud, aga paljud allikad on veel avaldamata ja puudub ühtne andmebaas. Seda andmestikku tuleks täiendada mujal asuvate allikatega, et jõuda lõpuks kõigi teadaolevate keskaegset Liivimaad või vähemalt tema Eesti-osa puudutavate allikate digitaalse kättesaadavuseni. Tegu oleks niisiis korraga nii allikateaduse ja arhiivinduse kui ka digihumanitaaria valda jääva algatusega. Sellega oleks loodud alus edasisteks uurimusteks, mis ei käsitleks ainult poliitilist ja majandusajalugu, vaid ka muid valdkondi, alates territooriumi uurimisest kuni prosopograafiani. Tõepoolest, olemasolevad Liivimaa vaimulikkonna ja Saksa Ordu kohalike rüütlite nimekirjad saaksid olulise täienduse ja me saaksime koostada keskaegse Eesti tähelepanuväärsemate elanike loendi. Samas tuleks lõpule viia territooriumi kaardistamine, toetudes nii arheoloogilistele kui ka kirjalikele allikatele.

Tegeledes varem vähem käsitletud teemadega, oleme veidi unustanud talurahva ajaloo, arvates, et seda uuriti okupatsiooni ajal juba piisavalt. Varem või hiljem jõutakse selle teema juurde tagasi ja kujutan ette, et lähtudes 16. sajandi protestantlikest kirikuvisitatsioonidest ja minnes arheoloogide abiga ajas üha enam tagasi, saab ka „maarahva“ ajalugu uue vaatenurga. Arvata on, et võtmeküsimuseks saab mitte ainult pärimuskultuuri, vaid ka antropoloogia lõimimine ajaloouuringutesse. Teisalt pakub aga Hansa majandusruumi ja meie kaupmeeskonna ajalugu, kuigi seda on palju uuritud, veel suurel hulgal avaldamata ja tundmatut materjali.

Kokkuvõtteks, oskamata tulevikku ennustada, pakuksin siiski, et järgmised olulised sammud tehakse „rohujuure“ tasandil, võttes käsile allikmaterjali ja kohaliku ühiskonna, alates selle madalamatest kihtidest. Samaaegselt oleks tegemist nii protsessiga, mida määratletakse kui mapping, s.o allikate ja territooriumi „,kaardistamine“, kui ka ühiskonna majanduslike alustalade uurimisega. Kõik see eeldab koostööd, igas vallas ja mõttes, ning oskust säilitada avalikkuse huvi ajalooteaduse vastu. 


\title{
FORUM: WHAT IS THE FUTURE OF HISTORICAL RESEARCH IN ESTONIA?
}

\author{
Liisi ESSE, Andres KASEKAMP, Jüri KIVIMÄE, Mart KULDKEPP, \\ Anu Mai KÕLL, Kristo NURMIS, Kristjan TOOMASPOEG
}

This collective discussion forum, consisting of seven short essays, proposes some future scenarios for Estonian historical research in the next couple of decades. The Estonian historians participating in the forum represent different generations - from $\mathrm{PhD}$ students to emeritus professors, but they all have been or still are active in various universities across the world, mostly in Europe and in the Northern America. This means that the forum aims also to offer an external regard to the future development of historical studies in Estonia. Some of the main issues covered in the forum are the following: Estonian history needs a more comparative and transnational perspective; interdisciplinary cooperation is still not sufficiently integrated in the historical research; historiographical and theoretical self-reflection should deserve more attention; the new digital tools and digitized materials needs to be used more widely in historical studies. Topic wise, the main desiderata mentioned in the forum are the mapping of medieval sources, institutions and local populations in Livonia, the study of the 1905 revolution and its impact on Estonian independence movement, the comparative study of Soviet Estonian history, the research into regaining of the independence and rebuilding of the Estonian state in late 1980s and 1990s. 